\section{APPLICATION OF THE THEORETICAL MODEL IN NORMALIZATION OF VERTICAL JUMP TEST RESULTS WITH RESPECT TO THE BODY MASS}

\author{
PRIMJENA TEORIJSKOG \\ MODELA U NORMALIZACIJI \\ REZULTATA TESTOVA \\ VERTIKALNOG SKOKA U ODNOSU \\ NA TJELESNU MASU
}

\section{SUMMARY}

The aim of this study was to examine the efficiency of application of the theoretical model in normalization of motor ability tests in order to neutralize the influence of body mass on muscle strength during various vertical jumps. The sample of participants was consisted of 60 basketball players that play in positions of power forward and center. Independent variables were body mass, body height and body fat percentage, whereas dependent variables were divided into variables that directly and indirectly estimate muscle strength during various vertical jumps. The results of motor ability tests were normalized using a theoretical exponent $b=0,67$ for direct assessment of muscle strength, while exponent $b=0$ was used for indirect muscle strength assessment. Based on the obtained results it has been concluded that: 1) before the normalization of the vertical jump test results, there was a moderate positive correlation between the results of the direct muscle strength assessment and body mass (0,44; $0,38)$ and 2) a correlation between the tests of the indirect muscle strength assessment and body mass was inadequate (-0,09;-0,14). After the application of the theoretical model in normalization of results, it has been noted that correlation coefficients decrease between the tests of direct muscle strength assessment and body mass (-0,08;-0,14). Correlation coefficients in the indirect muscle strength assessment tests remained unchanged (-0,09;-0,14). In that way, we obtained muscle strength results in vertical jumps independently from the body mass.

Keywords: geometric scaling, vertical jump, maximal muscle strength, body mass. 


\section{INTRODUCTION}

One of the constant research subjects in physical education, sport and recreation is the influence of certain body dimensions on one's motor abilities. From all of body dimensions, a influence of body mass on the motor ability results, was the most frequent one. An influence of locomotor apparatus on its movement mechanics is called the scale effect, and relating some mechanical measure that describes movement with certain body dimension is called scaling (Jarić, 1997). Relative power or force is frequently assessed in sport diagnostics with respect to body mass as a quotient of overpowered external loads and body mass. Some authors present normalization of motor ability tests per kilo of body mass (Frontera, Hughes, Lutz \& Evans, 1991; Hakkinen, Komi \& Alén, 1985). On the other hand, there are authors who consider this way of results normalization inappropriate, thence they proved through a series of studies nonlinear dependence of body dimensions and motor abilities, i.e. the test results are related to $\mathrm{m}^{2 / 3}$ (Nevill, Ramsbottom \& Williams, 1992; Jarić, 2002, 2003; Nevill, 1995; Winter, 2005; Marković \& Jarić, 2007). Simple example of scale effect significance is seen in the results of weight lifters. Wu Jingbiao who competed in $65 \mathrm{~kg}$ category, has set a world record in snatch discipline lifting load of $139 \mathrm{~kg}$. Since relative power is equal to the quotient of overpowered load and body mass, it means that his relative power is equal to 2,48 . Besides, if a heavy category athlete $(+105 \mathrm{~kg})$ has a relative power of 2,48 , it means that he would be able to lift $260,4 \mathrm{~kg}$. However, the world record holder, Bulgarian Aramnau Andrei, in that particular discipline managed to lift $200 \mathrm{~kg}$. On that ground, it could be concluded that body mass and force are not proportionate and with an increase of body mass exertion of muscle power decreases, i.e, it increases with $\mathrm{m}^{2 / 3}$. Another example that indicates the significance of the scale effect is the assessment of relative oxygen consumption $\left(\mathrm{VO}_{2} \mathrm{max}\right)$ expressed in milliliters per kilo of body mass in minute $(\mathrm{ml} / \mathrm{kg} / \mathrm{min})$. Although it is known that strength is proportional to the metabolic energy consumption, that is both measures rise with $\mathrm{m}^{2 / 3}$, common practice is to determine relative oxygen consumption by body mass unit $(\mathrm{m})$, not by $\mathrm{m}^{2 / 3}$. In that way, errors are continuously being made in presenting the results of maximum oxygen consumption.

For the results normalization of motor ability tests, today usually two models are being applied: theoretical model or geometrical scaling and experimental model or allometric scaling. Both models are frequently used in practice, and the difference between these two models is very small. If the scale effects would be tested in people with very different body dimensions, the difference between these two models would be more evident. Beside these two models, a model of multiple regression is applied in practice too. Its advantage lays in the facts that in results normalization, apart from body dimensions, other factors that influence functional and motor abilities are included.

Geometric scaling is based on theory of geometric similarity, which implies that difference between two persons exists only in their dimensions. If a body is two times size of another body, then all length measures of that body will be two times bigger, all body surface measures would be $2^{2}=4$ larger, and all volumes, masses and weights $2^{3}=8$ larger. Geometric scaling applied on humans considers that all human bodies are of the same shape, and difference exists only in their dimensions. That is why the ratio of various body lengths would be equal for all people. Since the differences in humans' length dimensions are usually smaller than 2:1 ratio, then for practical reasons it would be best to present body dimensions ratio $l=1$. Number $l$ would be 1.05 if the first person were $5 \%$ taller from the second person, or 0.97 , if he is $3 \%$ shorter than the second person is. Consequently, a person is $l$ times taller or shorter than other person, and

Kukrić,A. et al.:Application of theoretical model...Sportlogia 2017, 13 (1), 9-17. Page 10. 
therewith all other length measures (length of extremities, chest circumference, joint diameters ...) are differing for $l$ times. All body surface areas differ $l^{2}$ times (body surface area, the area of physiological muscle cross-section, the area of physiological bone cross-section...). All volumes, and more importantly, mass and body weight of a person differ $l^{3}$ times (body mass, body parts weight...). For example, if a person is $10 \%$ taller than the other person $(l=1.1)$, than all of its body lengths are bigger for $10 \%$, all body area surfaces larger for $21 \%\left(1^{2}=1,21\right)$, and all masses and weights $33 \%$ heavier $\left(1^{3}=1,33\right)$. Using the principles of geometric scaling, the scale effects on human strength were explained. Recorded muscle force $(\mathrm{F})$ depends on muscle force $(\mathrm{Fm})$ and lever quotient (k), namely $F=F m \times k$. If a body dimensions change for $l$ times, both moment arms proportionally change and their ratio $\mathrm{k}=\mathrm{a} / \mathrm{b}$ stays unchanged. Therefore, when body dimensions change, lever quotient of locomotor apparatus remains intact. Muscle force (power), inter alia, largely depends on muscle cross-section. As any other surface, it is proportional with $l^{2}$, i.e. total muscle power is proportional with $l^{2}\left(\mathrm{~F}=l^{2}\right)$. This suggests that results on all strength tests will rise with the square of body height. The most common way of muscle strength results normalization relates to body mass, because body height tends to be unreliable index in normalization of results. It is already mentioned that mass rises with $l^{3}$, or vice versa, length increases with cube root of mass $l \sim \mathrm{m}^{1 / 3}$. Hence is $l^{2} \sim \mathrm{m}^{2 / 3}$, and the total muscle strength will be equal $\mathrm{F}=\mathrm{m}^{2 / 3}$. It can be concluded that the forces that a man generates proportional to the third root of the square of his body mass (Jarić, 1997).

Geometric scaling of different groups of motor ability tests, with respect to the body mass, yields different exponents. Fleishman (1964) allocates vertical jumps into the group of tests that estimate rapid-motions. Accordingly, this study will consider only exponents that relate to that group of tests. The exponents that are used for normalization of results in other motor ability tests would not be presented. The results of direct muscle strength assessment when performing rapidmotions are normalized with $m^{2 / 3}$, and theoretically proposed exponent for results normalization is $b=0,67$. The results of indirect muscle strength assessment when performing quick moves are normalized with $m^{0}$, and theoretically proposed exponent for results normalization is $b=0$ (Aasa, Jarić, Barnekow-Bergkvist \& Johansson, 2003; Jarić, 2002).

The aim of this study was to examine the efficiency of application of the theoretical model in normalization of motor ability tests in order to neutralize the influence of body mass on muscle strength during various vertical jumps.

\section{METHODS}

Male basketball players $(\mathrm{N}=60)$, members of Bosnia \& Herzegovina Premier League and First League of Republic of Srpska, participated in this study. Participants were selected according to their playing positions to power forwards and centers, which are commonly known in basketball as inside players. All participants were healthy, without injuries of lower extremities that could affect results of testing. Participants gave formal consent for all measurements and testing.

Variables were divided into two groups. Independent variables were body mass (BM), body height $(\mathrm{BH})$ and body fat percentage (BFP) and they represented morphological characteristics of the participants. Using the bioelectric impedance method (Tanita BC 418), a body composition was measured, and precise data on the body mass and percentage of the fat tissue of the subjects were obtained. The height measurer ( $\mathrm{Seca}$ ) was used to measure the body height of the examinees. Since tests for the assessment of rapid-motion can be subdivided into tests of direct and indirect muscular assessment, dependent variables are divided into two groups.

Kukrić,A. et al.:Application of theoretical model...Sportlogia 2017, 13 (1), 9-17. Page 11. 
Using force platforms (Globus Ergo Tesys System 1000, Mega Twin Plates) in direct muscle strength tests, the vertical component of the ground reaction force was measured to two different vertical jumps. Only the exerted power (W) in the concentric phase of the jump with the isolated hands on hips (Countermovement jump-CMJP) was analyzed, and in the jump from the squat position with hands isolated on hips (Squat jump-SJP). In the tests of the indirect estimation of the muscular strength, during the performance of different variants of the vertical jump, the maximum jump height was measured, and the obtained value was expressed in centimeters $(\mathrm{cm})$.

Vertical jump with isolated hands on the hips is performed when the subject from the vertical position lowers to the squat position and, without stopping, at the point of movement direction change (the angle of the thighs and lower legs approximately is $90^{\circ}$ ), performs the maximum vertical jump. Three attempts were performed, and the best result was recorded for further analysis.

The data were analyzed by descriptive and comparative statistical procedures. Within the descriptive statistics for all variables are determined: arithmetical mean, standard deviation, minimum and maximum. Correlation analysis was applied in the context of the comparative statistics (Pearson method). All collected data were processed using the statistical program Statistics 7.

\section{RESULTS}

Table 1 presents the descriptive parameters (arithmetic mean (Mean), standard deviation (SD), range (minimum and maximum values) of morphological characteristics (body height, body mass and body fat percentage) and motor abilities of basketball players (vertical jump with isolated hands on the hips, vertical squat jump with hands isolated on hips).

Table 1. Descriptive parameters of morphological characteristics and motor abilities of basketball players

\begin{tabular}{ccc}
\hline Variable & Range & Mean \pm SD \\
\hline BH $(\mathrm{cm})$ & $179.50-211.00$ & $197.77 \pm 8.13$ \\
BM $(\mathrm{kg})$ & $70.70-115.40$ & $94.59 \pm 10.58$ \\
BFP (\%) & $5.50-19.70$ & $12.01 \pm 3.34$ \\
CMJ (cm) & $26.00-46.00$ & $34.18 \pm 4.43$ \\
CMJP (W) & $3251.60-6298.90$ & $4652.51 \pm 679.08$ \\
SJ (cm) & $24.00-45.00$ & $32.80 \pm 4.41$ \\
SJP (W) & $2662.60-5797.20$ & $4525.77 \pm 659.51$
\end{tabular}

Legend: BH-Body height; BFP-Body fat percentage; BM-Body mass; CMJ-Countermovement jump with hands isolated on hips; CMJP-Maximal strength in CMJ; SJ-Squat jump with hands isolated on hips; SJP-Maximal strength in $\mathrm{SJ}$

Table 2 shows the interconnection between the body mass and the results of the motor ability tests of the basketball players before and after the application of the theoretical model in the normalization of the result. Above the diagonal is shown the correlation of the results before,

Kukrić,A. et al.:Application of theoretical model...Sportlogia 2017, 13 (1), 9-17. Page 12. 
and below the diagonal after applying the theoretical model in the normalization of motor skills in relation to the body mass.

Table 2. Correlation of the body mass and the results of the motor ability tests of the basketball players before and after the data normalization

\begin{tabular}{cccccc}
\hline & BM & CMJ & CMJP & SJ & SJP \\
\hline BM & 1.00 & -0.09 & $0.44^{*}$ & -0.14 & $0.38^{*}$ \\
CMJ & -0.09 & 1.00 & 0.16 & 0.96 & 0.13 \\
CMJP & -0.08 & $0.41^{*}$ & 1.00 & 0.06 & 0.58 \\
SJ & -0.14 & 0.96 & 0.34 & 1.00 & 0.11 \\
SJP & -0.14 & 0.36 & 0.48 & $0.37^{*}$ & 1.00 \\
\hline
\end{tabular}

Legend: BM-Body mass; CMJ-Countermovement jump with hands isolated on hips; CMJP-Maximal strength in CMJ; SJ-Squat jump with hands isolated on hips; SJP-Maximal strength in SJ

\section{DISCUSSION}

Comparing the body dimensions of the tested participants (Table 1) with similar studies (Drinkwater, Pyne \& McKenna, 2008; Jeličić, Sekulić \& Marinović, 2002 Ostojić, Mazić \& Dikić, 2006) one can see that this is about a selected sample of basketball players, whose measures of body mass, body height and body fat percentage are of approximately similar values with the European basketball players at inside positions. Since in most studies, body height, isolated from the other body dimensions, proved to be an unreliable index to normalize results (Jarić, 2002, Marković \& Jarić, 2005), the test results were normalized only in relation to the body mass. According to the theory of geometric similarity of the people, exerted muscle strength in the tests of direct muscle strength assessment is dependent on the body mass, and it is necessary to normalize the results, while the indirect assessment tests of muscle strength is not dependent on body mass (Aasa, Jarić, Barnekow- Bergkvist \& Johansson, 2003; Marković, Mirkov \& Jarić, 2005; Marković \& Jarić, 2007). In the sample of students in the Faculty of Kinesiology in Zagreb, Marković tested any difference between the vertical jumping ability tests in concentric and eccentric-concentric mode. He obtained approximately the similar values of theoretically predicted exponents. Analyzing the Squat jump, in relation to the body mass, he found the exponent $b=0.68$, that is, $b=0.82$ when it comes to Countermovement jump. When he observed the results in relation to the height of the jump expressed in centimeters, he obtained in both jumps exponents near zero (Marković \& Jarić, 2005). These results point to the conclusion that it is unnecessary to normalize the results of the tests if they are estimated as the height of the jump expressed in centimeters.

Based on the results presented in Table 2, it can be concluded that prior to the normalization of the results of vertical jump tests, there was a moderate positive correlation between the results of the tests of direct muscle strength and body mass assessment, which is confirmed by the correlation coefficients $(0.44 ; 0.38)$. Low coefficients of the correlation $(-0.09$; 0.14) confirm the lack of connection between the tests of an indirect assessment of muscle

Kukrić,A. et al.:Application of theoretical model...Sportlogia 2017, 13 (1), 9-17. Page 13. 
strength and body mass. After the application of the theoretical model in the normalization of the results, a decrease in the correlation coefficient between the direct estimation of muscular strength and body mass was noted $(-0.08 ;-0.14)$. The correlation coefficients in the tests of the indirect muscle power estimation remained unchanged $(-0.09 ;-0.14)$ because they were normalized with $m^{0}$. The obtained results are in line with previous research (Marković \& Jarić, 2005, 2007; Nedeljkovic, Mirkov, Kukolj, Ugarković \& Jaric, 2007; Crewther, Gill, Weatherby \& Lowe, 2009; Crewther, Kilduff, Cook, Cunningham, Bunce, Bracken \& Gaviglio, 2012). In addition, due to the normalization of results, the correlation between the results of tests of direct and indirect estimation of muscular strength in the performance of different variants of vertical jumps has increased. This is also confirmed by the correlation coefficients before $(0.16 ; 0.11)$ and after $(0.41 ; 0.37)$ normalization of the result.

The applied theoretical model in the data normalization proved to be effective in neutralizing the impact of body mass on the results of motor ability tests. Geometric scaling neutralized the effect of body mass on the manifestation of muscular strength in tests of direct muscle strength assessment when performing different variants of vertical jumps. Similar conclusions were reached by Crewther and associates in two studies (2009 and 2012) testing rugby players in different playing positions.

\section{CONCLUSION}

In a broader sense, the aim of the research was to point out the mistakes that are often found in sports practice in testing the functional and motor abilities of athletes, which relate to the normalization of results with respect to the body mass. In the narrow sense, the aim of the research was to prove that by applying the theoretical model in the normalization of the results of motor test of motor abilities successfully neutralizes the influence of the body mass on the manifestation of muscular strength in the performance of various vertical jumps. The results of the research have shown that muscular strength and body mass do not have a linear relationship, but with an increase in body mass, the muscle strength grows slower. Theoretically predicted exponents for the tests of direct and indirect muscular strength assessment in performing rapidmoves, in this case of vertical jumps, successfully neutralize the effect of body mass, so that results of vertical jumps are independent of the body mass. Based on the results, one general conclusion could be made: the body mass influences the exertion of muscular strength in a vertical jump, but does not affect the height of the jump. The significance of the research is also reflected in the fact that the research was conducted on a selected sample of basketball players, characterized by the body dimensions significantly different from the average population. In future research, it would be interesting to analyze the effects of the scale in people with distinctly different body dimensions, different sex, age and race. Then the significance of normalizing the results using one of the models would be even more obvious.

\section{REFERENCES}

Aasa, U., Jarić, S., Barnekow-Bergkvist, M., \& Johansson H. (2003). Muscle strength assessment from functional performance tests: role of body size. Journal of Strength and Conditioning Research, 17(4), 644-670.

Kukrić,A. et al.:Application of theoretical model...Sportlogia 2017, 13 (1), 9-17. Page 14. 
https://doi.org/10.1519/00124278-200311000-00007

https://doi.org/10.1519/1533-4287(2003)017<0664:MSAFFP $>2.0 . C O ; 2$

Crewther, B. T., Kilduff, L. P., Cook, C. J., Cunningham, D.J ., Bunce, P. J., Bracken, R. M., \& Gaviglio, C. M. (2012). Scaling strength and power for body mass differences in rugby union players. Journal of Sports Medicine and Physical Fitness, 52(1), 27-32.

PMid:22327083

Crewther, B.T., Gill, N., Weatherby, R. P., \& Lowe, T. (2009). A comparison of ratio and allometric scaling methods for normalizing power and strength in elite rugby union players. Journal of Sports Science, 27(14), 1575-1580.

https://doi.org/10.1080/02640410903348657

PMid:19967595

Drinkwater, E. J., Pyne, D. B., \& McKenna, M. J. (2008). Design and interpretation of anthropometric and fitness testing of basketball players. Sports Medicine, 38(7), $565-$ 578.

https://doi.org/10.2165/00007256-200838070-00004

PMid:18557659

Fleishman, E. A. (1964). The structure and measurement of physical fitness. Englewood Cliffs, N.J.: Prentice Hall.

Frontera, W. R., Hughes, V. A., Lutz K. J., \& Evans, W. J. (1991). A cross-sectional study of muscle strength and mass in 45- to 78-yr-old men and women. Journal of Applied Physiology, 71(2), 644-650.

PMid:1938738

Häkkinen, K, Komi, P. V., \& Alén, M. (1985). Effect of explosive type strength training on isometric force- and relaxation-time, electromyographic and muscle fibre characteristics of leg extensor muscles. Acta Physiologica Scandinavica, 125(4), 587600 .

https://doi.org/10.1111/j.1748-1716.1985.tb07760.x

https://doi.org/10.1111/j.1748-1716.1985.tb07759.x

PMid:4091002

Jarić, S. (1997). Biomehanika humane lokomocije sa biomehanikom sporta. Beograd, RS: Dosije.

PMCid:PMC1184399

Jarić, S. (2002). Muscle strength testing: use of normalisation for body size. Sports Medicine, 32(10), 615-631.

https://doi.org/10.2165/00007256-200232100-00002

PMid:12141882

Jarić, S. (2003). Role of body size in the relation between muscle strength and movement performance. Exercise and Sport Science Reviews, 31(1), 8-12. https://doi.org/10.1097/00003677-200301000-00003

Jeličić, M., Sekulić, D., \& Marinović, M. (2002). Anthropometric characteristics of high level european junior basketball players. Collegium Antropologicum, 26, 69-76. PMid:12674837

Markovic, G., \& Jarić, S. (2005). Scaling of muscle power to body size: the effect of stretchshortening cycle. European Journal of Applied Physiology, 95(1), 11-19.

https://doi.org/10.1007/s00421-005-1385-5

PMid:16007449

Kukrić,A. et al.:Application of theoretical model...Sportlogia 2017, 13 (1), 9-17. Page 15. 
Markovic, G., \& Jarić, S. (2007). Is vertical jump height a body size independent measure of muscle power? Journal of Sport Science, 25, 1355 - 1363.

https://doi.org/10.1080/02640410601021713

PMid:17786688

Marković, G., Mirkov, M., \& Jarić, S. (2005). Maximum exercise performance and body size. Nova Science Publishers, 167-185.

PMCid:PMC4436647

Nedeljkovic, A., Mirkov, D. M., Kukolj, M., Ugarković, D., \& Jarić, S. (2007). Effect of maturation on the relationship between physical performance and body size. Journal of Strength and Conditioning Research, 21(1), 245-250.

https://doi.org/10.1519/00124278-200702000-00044

PMid:17313295

Nevill, A. M. (1995). Scaling, normalizing, and per ratio standards: an allometric modeling approach. Journal of Applied Physiology, 79, 1027-1031.

PMid:8567498

Nevill, A. M., Ramsbottom, R., \& Williams, C. (1992). Scaling physiological measurements for individuals of different body size. European Journal of Applied Physiology, 65, $110-117$. https://doi.org/10.1007/BF00705066

Ostojic, S. M., Mazić, S., \& Dikić, N. (2006). Profiling in basketball: physical and physiological characteristics of elite players. Journal of Strength and Conditioning Research, 20(4), 740-744.

https://doi.org/10.1519/00124278-200611000-00003

https://doi.org/10.1519/R-15944.1

PMid:17149984

Winter, E.M. (2005). Jumping: power or impulse. Medicine and Science in Sports and Exercise, 37, 523.

https://doi.org/10.1249/01.MSS.0000155703.50713.26

Received: 22.05.2017.

Accepted: 02.06.2017.

Correspondence author:

Aleksandar Kukrić, $\mathrm{PhD}$

Faculty of Physical Education and Sport

University of Banja Luka

Bosnia and Herzegovina

aleksandar.kukric@fffvs.unibl.org

Kukrić,A. et al.:Application of theoretical model...Sportlogia 2017, 13 (1), 9-17. Page 16. 


\section{SAŽETAK}

Cilj istraživanja bio je da se ispita efikasnost primjene teorijskog modela u normalizaciji rezultata testova motoričkih sposobnosti u svrhu neutralisanja uticaja tjelesne mase na ispoljavanje mišićne snage pri izvođenju različitih vertikalnih skokova. Uzorak ispitanika činilo je 60 košarkaša koji u svojim timovima igraju na pozicijama krilnog centra i centra. Nezavisne varijable bile su tjelesna masa, tjelesna visina i procenat masnog tkiva, dok su zavisne varijable podijeljene na varijable koje direktno i indirektno procjenjuju mišićnu snagu pri izvođenju različitih vertikalnih skokova. Rezultati testova motoričkih sposobnosti normalizovani su koristeći teorijski predviđen eksponent $b=0,67$ za direktnu procjenu snage mišića, dok je za indirektnu procjenu snage mišića korišten eksponent $b=0$. Na osnovu dobijenih rezultata zaključeno je: 1) prije normalizacije rezultata testova vertikalnih skokova postoji umjerena pozitivna povezanost između rezultata testova direktne procjene mišićne snage i tjelesne mase $(0,44 ; 0,38) i 2)$ izostala je povezanost između testova indirektne procjene mišićne snage $i$ tjelesne mase (-0,09;-0,14). Nakon primjene teorijskog modela u normalizaciji rezultata zabilježeno je smanjenje koeficijenta korelacije između testova direktne procjene mišićne snage $i$ tjelesne mase (-0,08;-0,14). Koeficijenti korelacije u testovima indirektne procjene mišićne snage ostali su nepromijenjeni (-0,09;-0,14). Na taj način dobijeni su rezultati mišićne snage $u$ vertikalnim skokovima nezavisni od tjelesne mase.

Ključne riječi: geometrijsko skaliranje, vertikalni skok, maksimalna snaga mišića, tjelesna masa

Kukrić,A. et al.:Application of theoretical model...Sportlogia 2017, 13 (1), 9-17. Page 17. 